\title{
Testing the Impact of Brief Counseling on Non-Urgent Client Self-Esteem, Social Connectedness, Recommending Their University and Active Alumnus Intent
}

\author{
Gary Blau ${ }^{1}$, John DiMino ${ }^{2}$, Allyce Barron ${ }^{1}$, Kathleen Davis ${ }^{1}$, Kelly Grace $^{1}$ \&Andrea B. Lopez ${ }^{1}$ \\ ${ }^{1}$ Fox School of Business, HRM Department, Temple University, Philadelphia, PA, USA \\ ${ }^{2}$ Tuttleman Counseling Services Center, Temple University, Philadephia, PA, USA \\ Correspondence: Gary Blau, HRM Department, Fox School of Business, 1810 Liacouras Walk, Temple \\ University, Philadelphia, PA 19122, USA. Tel: 1-215-204-6906. E-mail: gblau@temple.edu
}

\author{
Received: May 17, 2018 Accepted: June 4, 2018 Online Published: June 11, 2018 \\ doi:10.5539/jedp.v8n2p29 \\ URL: http://doi.org/10.5539/jedp.v8n2p29
}

\begin{abstract}
The purpose of this study was to test brief counseling impact on four outcomes. Two outcomes, self-esteem and social connectedness, were more typical for a University Counseling Center (UCC) to address. However, two other outcomes were more related to a university's academic mission, i.e., recommending the university and active alumnus intent. Using a longitudinal sample of 60 matched non-urgent undergraduate clients at a UCC, brief counseling increased all four outcomes: social connectedness, self-esteem, recommending the university, and active alumnus intent. For this study, brief counseling was defined as a median of three counseling sessions after intake (range 1 to 8 ) over a median period of six weeks (range 4 to 10 weeks). In addition, these scale means were compared to a control group of business undergraduates not in counseling. The counseled sample at Time 2 compared favorably to the non-counseled sample on recommending the university and active alumnus intent. To better support its students' success and university enrollments, UCCs need to consider new avenues to promote their advocacy by gathering data more directly connected to a university's mission.
\end{abstract}

Keywords: recommending the university, alumnus intent, social connectedness, self-esteem, non-urgent clients, brief counseling

\section{Introduction}

Within higher education institutions, student mental health service needs are on the rise. The most recent reports by the Center for Collegiate Mental Health (CCMH, 2017) and the Association for University and College Counseling Center Directors (AUCCCD, 2016) confirmed this trend. Despite the increased demand for these services, the AUCCCD (2016) found that $56 \%$ of the University College Counseling (UCC) Directors indicated that their operating budgets had remained unchanged for the past year. There are also changes occurring in the types of mental health services being provided. A survey by the CCMH (2017) showed that "on average UCCs are providing $28 \%$ more 'rapid-access' service hours per client and $7.6 \%$ fewer 'routine' service hours per client over the last six years" (p.3). The CCMH (2017) report noted that, especially for UCCs with funding that has not kept up with demand, this may negatively impact routine service availability after initial client contact. As a result, the CCMH (2017) encouraged UCCs to attend to routine treatment capacity and not just the speed of initial response. Adequate resource allocation is an important issue as UCCs compete with other campus stakeholders for resources (Kitzrow, 2009). Given that, it is important to establish the variety of ways that counseling centers contribute to the overall health of their institutions, the general purpose of this study was to explore the impact of brief counseling services on a sample of non-urgent clients recommending their university and intent to be an active alumnus.

\subsection{Broadening the UCC Focus to Include Academic Goals}

Standardized mental health measures such as the Behavioral Health Measure or BMH (Kopta et al., 2014), and Counseling Center Assessment of Psychological Symptoms or CCAPS (Brunner, Wallace, Reymann, Sellers \& McCabe, 2014) are often used by UCCs to evaluate their services. While evaluating mental health data is certainly important, Corazzini (1997) noted that "the future of a counseling center is more promising when counseling is seen in relation to the academic mission" (p. 380). Archer and Cooper (1998) noted that one issue for a UCC can be integrating the services it provides with academic goals. For instance, one accepted goal of educational institutions 
has been to increase student retention, allowing them to graduate in a timely manner (Raju \& Schumacker, 2015). Research has shown that counseling can increase student retention and graduation (Lee, Olson, Locke, Michelson \& Odes, 2009). Sustainability through enrollment and adequate funding have also been accepted goals of a university's mission (Hamadeh \& Khoueiri, 2010).

\subsection{Recommending the University}

Bishop (2010) noted that a UCC was typically an "undervalued resource in recruitment, retention and risk management" (p. 248). The availability of mental health services can affect potential student enrollees' and their families' perceptions of how well-cared-for the student will be, which may affect their matriculation choice (Bishop, 2010). The second author, the director of a UCC, anecdotally reports that in recent years he and his staff have fielded a greater number and variety of questions from both parents and students about the resources of the counseling center both before and after a commitment is made to the university. In fact, proper staffing level based on the International Association of Counseling Services or IACS (2010) can help to assure prospective students (and their families) about campus priorities.

Vianden (2015) has argued that undergraduates are "partners to higher education institutions in establishing the educational enterprise" (p. 287). Viewing students as customers and measuring their willingness to recommend the university can help the university achieve long-term sustainability (Browne, Kaldenberg, Browne \& Brown, 1998). Working with a sample of 117 non-urgent undergraduates who completed a survey after triage (initial screening) and before intake (meeting their assigned therapist), Blau, DeMaria and DiMino (2017) found that perceived service promptness from the UCC positively explained recommending the university beyond controls for demographics (e.g., gender, ethnic background), and client perceptions (e.g., stigma for counseling, wait time). The perceived responsiveness of the institution may be acutely important when a student feels in need of help (Mowbray et al., 2006). For such a student, the UCC therapist may represent the institution.

With the availability of social media, college students have increasing access to friends and acquaintances (Ellison, Steinfield \& Lampe, 2007), so their audience for recommending a university has increased. Students having a positive UCC counseling experience can serve as "good-will ambassadors", and be more likely to recommend the university to others. Counseling outcomes are one consideration that may affect their recommendation. Waiting time between triage and intake is another. Blau et al. (2015) found that the "less wait time" (up to two weeks) group of non-urgent clients $(\mathrm{n}=48)$ were more likely to recommend their university than the "more wait time" (at least two weeks) group $(\mathrm{n}=51)$.

\subsection{Active Alumnus Intent}

As many universities and colleges contend with the economic realities of the need to increase tuition and/or lower government subsidies, one source of increased revenue is alumni donations (Worth, 2002). The majority of a university's benefactors have been shown to have a direct connection to the institution they donate to, i.e., alumni (Williams \& Kritsonis, 2006).

In fact, alumni donations accounted for $26.1 \%$ of the philanthropic gifts to higher education in 2017 (Joslyn, 2018). While being an active alumnus can include monetary donations, it can also involve attending alumni events, interviewing prospective students, or mentoring a current student (Torres Bernal \& Mille, 2014). Active alumni were more likely to remember positive and/or growth-related experiences at their institutions, e.g., social engagement with students or social organizations, or academic engagement with specific professors (Weerts \& Ronca, 2007). Undergraduate students recalled specific critical incidents where counseling center staff were helpful (Vianden, 2015), which motivated these students to return for additional counseling. Further, the therapeutic alliance between a therapist and client may be an example of a specific positive and/or growth experience for a counseled student (Pinkerton, Tally, \& Cooper, 2009). Such a student may be more likely to become an active alumnus.

\subsection{Generally Brief Nature of College Counseling}

College student counseling is typically of short duration. Draper, Jennings, Baron, Ozgur and Shankar (2002) found that the average number of sessions per client was 3.3 for their undergraduate client sample. Ghetie (2007) noted a median of 4-5 counseling sessions and a mode between 1 and 2 sessions. Mahon et al. (2015) found that only $37 / 124(30 \%)$ of undergraduate clients completed a minimum of three counseling sessions. The $2016 \mathrm{CCMH}$ report (CCMH, 2017) noted a mode of one for the number of appointments.

When simultaneously comparing in-counseling versus not-in-counseling undergraduate samples, researchers have reported that students who are in-counseling have significantly lower academic adjustment, social adjustment and personal emotional adjustment (DeStefano, Mellott \& Petersen, 2001), as well as lower perceived well-being and 
mental health (Green, Lowry \& Kopta, 2003). Prior research suggests that even a short-term intervention can increase important undergraduate mental health outcomes. Mahon et al. (2015) found a significant decrease in counselor-reported client symptom severity. In a separate study, Blau, DiMino, DeMaria, Beverly and Chessler (2016) found that a four-session median length of counseling led to a significant decrease in non-urgent client mental health concerns. This prior research collectively suggests that brief counseling may positively impact client social connectedness and self-esteem.

With a focus on recommending the university and active alumnus intent as the main study variables, the three hypotheses for this study were:

H1 - Brief counseling will increase social connectedness, self-esteem, recommending the university and active alumnus intent.

$\mathrm{H} 2$ - Social connectedness and self-esteem will be positively related to recommending the university and active alumnus intent.

H3 - Social connectedness and self-esteem will each account for significant variance in recommending the university and active alumnus intent beyond controlled-for background variables.

\section{Method}

\subsection{Samples and Procedure}

There were two samples collected for this study. One undergraduate sample was actively involved in counseling (i.e., counseling sample), and they were sampled twice over time, labeled as Time 1 and Time 2. The second sample consisted of undergraduate business students, not in counseling, labeled as Control. For the counseling sample, all data were voluntarily collected using two on-line surveys at the main campus of a large state-supported urban university's (University X) UCC in the Mid-Atlantic region of the United States. For any given client, the nature of his/her mental issue, as well as client/therapist availability, did not allow for a standardized number of sessions or time-periods as to when clients filled out the subsequent (Time 2) survey. As a result, a range of sessions and time-periods were used (reported below).

Data were collected from 332 undergraduates who registered for counseling services at the UCC between the fall of 2013 through the spring of 2017. The Institutional Review Board (IRB) approved all data collection methods, and clients submitted their data directly into Qualtrics' databases. The initial counseling session took the form of an in-person triage interview. At that time, these undergraduate students had been designated as non-urgent, i.e., non-suicidal or no risk to themselves or others, by the triage therapist. Non-urgent clients were asked if they wished to voluntarily participate in a research study by the triage therapists. The Time 1 clients took their survey after triage but before beginning counseling (i.e., intake). The time span between triage and intake could vary from that week to over three weeks, depending on service demand and therapist availability. Demographics for the Time 1 complete-data sample are reported below.

Undergraduate clients who completed the initial survey (Time 1) were asked to give the last four digits of their nine-digit university identity number so that their responses could be tracked over time while protecting their identities. Using a survey link, clients took the Time 1 survey either at the UCC's self-help center or at home. Using their email addresses recorded at triage, clients were contacted after their triage appointment, and asked to fill out a second survey approximately four weeks after triage, i.e., at Time 2. A four-week interval was used to try to maximize the response rate of the second survey, while also allowing for treatment improvement. Given the rolling nature of non-urgent client enrollment during a semester, along with respondent anonymity, a general email was sent out to all post-triage clients on a rolling weekly basis during that semester. As a check, clients were asked what survey they were filling out (Time 1, Time 2). Given respondent anonymity, it could not be determined if a particular client had stopped counseling.

Of the 332 initial participants, 306 (92\%) completed the Time 1 survey and are designated as Time 1. A sample of $\mathrm{n}=60 / 306(20 \%)$, based on the initial participants, completed the second survey at Time 2. This Time 2 sample reported a median of three counseling sessions after intake (range 1 to 8 ) over a median period of six weeks (range 4 to 10 weeks). Counseling sessions were delivered by UCC full-time professional staff, i.e., psychotherapists with a Ph.D., Psy.D., Ed.D., MSW or LCSW. No standardized procedures were used to assess the therapeutic methods employed. In order to improve the longitudinal response rate a $\$ 50$ random-drawing lottery for matched ID repeat-respondents was approved by the IRB partway through the data collection process. However, this incentive had little impact in improving the matched respondent participation rate. The complete data sample across both time-periods was $n=60$. The hypotheses tests are based on this $n=60$ sample. 
In the spring of 2014, data were collected on 914 complete-data undergraduates not currently in some type of counseling i.e., the Control sample. These students came from various business classes, including: human resources, marketing, finance, and business administration, and they were encouraged by their class professor to voluntarily complete an online survey. When asked "are you currently in some type of psychological counseling" on the survey, 57 (6\%) said "yes". These 57 students were eliminated from further data analyses, leaving a sample size of 857. Both samples, counseled Time 1 and Time 2, and the Control sample filled out the measures below, with the exception that the Control sample did not fill out any counseling-related items.

\subsection{Measures}

\subsubsection{Background Variables}

These variables were collected only at Time 1. Data collected included non-counseling-related items, i.e., gender, ethnic background, self-reported grade point average (GPA), age, and status as a full-time student (taking at least 12 credits/semester). Counseling-related items were: main mental health issue for presenting to counseling, and days told to wait for intake by the triage therapist (wait time)

\subsubsection{Social Connectedness and Self-Esteem}

For all measures below, a seven-point Likert scale was used, where $1=$ strongly disagree to $7=$ strongly agree, so the higher the score the greater the variable. Social connectedness was measured using four items. Items included: (1) "I feel like I have a lot in common with other students here at University X," (2) "I feel a strong sense of 'connectedness' with University X students," (3) "I have developed close interpersonal relationships here at University X," and (4) "when I think about my overall social life here, i.e., friendships, extracurricular activities, I feel good." Items represented the four highest loading items adapted from Davidson, Beck and Milligan's (2009) eight-item social integration scale. Prior research (Blau et al., 2016) found a Cronbach's alpha of .91 and .89 with two different samples using this four-item measure.

Self-esteem was measured using five items. Items included: (1) "I feel like I am a person of worth, at least on an equal basis with others," (2) "I feel like I have a number of good qualities," (3) "I am able to do things as well as most people," (4) "I take a positive attitude towards myself," and (5) "on the whole I am satisfied with myself." These were the positively worded items from Rosenberg's (1965) 10-item General Self-Esteem Scale. The other five reverse scored items from this scale were not used because research has shown that the negative items constitute a separate factor (Greenberger, Chen, Dmitrieva \& Farruggia, 2003), which was not relevant for this study.

\subsubsection{Recommending the University and Active Alumnus Intent}

Willingness to recommend the university (recommending the university) was measured using a three-item measure. Items included: (1) "I would recommend the university X to my friends and family," (2) "if asked I tell people that University X is a good place to go to college," and (3) "if someone asked me, I would not hesitate to endorse University X." Prior research (Browne et al., 1998) used a one-item measure, which does not allow for a reliability estimate. Blau et al. (2015) found a Cronbach's alpha of .92 using this measure.

Active alumnus intent was measured using a new study-specific three-item measure. Items included: (1) "I can see myself staying connected to University X after I graduate (e.g., attending events on campus or regionally)," (2) "I can see giving back to University X after I graduate (e.g., donating money, coming back to speak if asked)," and (3) "if asked, after I graduate I would be willing to interview prospective student applicants to University X or mentor a student." Item content was partially based on Weerts and Ronca (2007), and these items were pilot tested on a small, separate undergraduate sample.

\subsection{Data Analyses}

SPSS-PC (SPSS, 2013) was used to analyze the data. Hypothesis 1 (H1) was tested using paired sample t-tests for change from Time 1 to Time 2. Given the a priori hypothesis, one-tailed tests were used. Hypothesis 2 (H2) was tested using within-time period and across time period correlation analyses. Effect sizes for t-tests and correlations were also reported (Cohen, 1988). The third hypothesis (H3) was tested using hierarchical regression analyses (Stevens, 1996), using only Time 1 independent variables and Time 2 dependent variables. First, ethnic background was converted to a binary measure (non-white/white) so it could be directly entered into the regression models (Stevens, 1996). Following the logic of prior research (e.g., Blau et al., 2016; Blau et al., 2017), variables assumed to be more distally related to student outcomes, i.e., background, should be controlled for first, before testing the relationship of more proximally related variables, i.e., social connectedness and self-esteem. Thus, Time 1 background variables were entered into the regression models first (Step 1), before assessing the impact of 
Time 1 social connectedness and self-esteem, as client perceptions (Step 2), on Time 2 recommending the university and active alumnus intent outcomes. Given the limited sample size and to keep the ratio of subjects to variables at 10:1 for greater regression model stability (Stevens, 1996), gender and ethnic background were the only demographics entered in the regression models. However, GPA and age were separately tested and found to be unrelated to variables in the regression models. For the regression analyses it was determined that the assumptions of no multicollinearity, linearity, and homoscedasticity were satisfactorily met (Stevens, 1996). Care was taken to avoid several errors associated with hierarchical regression, i.e., neglect of a theoretical basis, violation of causal priority, and misinterpretation of results. The Control sample data were analyzed to provide perspective to the study's main results. A comparison was made on the four variable means of the counseled sample at Time 2 to the means of these variables for the non-counseled sample.

\section{Results}

\subsection{Demographic Comparisons of Counseling-Based to Control Samples}

Table 1 shows a demographic comparison of the counseling-based Time 1 sample $(\mathrm{n}=306)$ to the Time 2 sample $(\mathrm{n}$ $=60$ ). Across both samples there was general demographic agreement, although the percentage of males by Time 2 had dropped while, the percentage of female clients had increased. Consistent with the AUCCCD (2016) and CCMH (2017) reports, anxiety and depression were the two biggest mental health concerns for being treated. The UCC sample participant base of primarily white female was also consistent with these two reports. There were no significant differences between clients who completed the Time 2 measures versus those who did not. This supports the position that the missing data did not have systematic differences (Roth, 1994). Comparing these two counseling samples to the Control sample shows that while self-reported GPA, age and full-time student percentage data are consistent, there is a higher percentage of male and non-white participants in the Control sample.

Table 1. Demographic Variables for Time 1 and Time 2 Counseled and Control Samples

\begin{tabular}{|c|c|c|c|}
\hline Variable & Time $1(\mathrm{~N}=306)$ & Time $2(N=60)$ & Control $(N=857)$ \\
\hline \multicolumn{4}{|l|}{ Main Mental Health Issue } \\
\hline Anxiety & $41 \%$ & $34 \%$ & NA \\
\hline Depression & $29 \%$ & $37 \%$ & NA \\
\hline \multicolumn{4}{|l|}{ Gender } \\
\hline Male & $30 \%$ & $15 \%$ & $55 \%$ \\
\hline Female & $70 \%$ & $85 \%$ & $45 \%$ \\
\hline \multicolumn{4}{|l|}{ Ethnic background } \\
\hline Non-white & $27 \%$ & $28 \%$ & $38 \%$ \\
\hline White & $73 \%$ & $72 \%$ & $62 \%$ \\
\hline Self-reported GPA & 3.3 & 3.3 & 3.2 \\
\hline (range) & $(2.0$ to 4.0$)$ & $(2.0-4.0)$ & $(2.0-4.0)$ \\
\hline Age, M (range) & $21(18-26)$ & $22(18-26)$ & $22(18-26)$ \\
\hline $\begin{array}{l}\text { Mean Days Waited for Intake } \\
\text { (range) }\end{array}$ & $\begin{array}{c}14 \\
(1 \text { to } 40)\end{array}$ & $\begin{array}{c}14 \\
(1 \text { to } 40)\end{array}$ & NA \\
\hline Full-time Student (12 plus credits) & $94 \%$ & $92 \%$ & $95 \%$ \\
\hline
\end{tabular}

NA $=$ not applicable.

\subsection{Descriptive Data Results - Counseled Sample}

Table 2 shows the means, standard deviations, scale reliabilities and correlations for the matched timed counseled sample $(n=60)$. All reported scale means were divided by the number of items so that the reported mean is based on the 7-point response scale. All multi-item scales had strong reliability estimates, i.e., Cronbach's alpha (Nunnally, 1978). In addition, the re-test reliabilities (Time 1 - Time 2) for each measure were at least .77. The correlation matrix shows that there was sufficient discriminant validity to work with each scale separately (Stevens, 
1996).

Table 2. Means, Standard Deviations, Scale Reliabilities and Correlations for Matched Time 1 Wait Time, Time 1 Social Connectedness, Time 1 Self-Esteem, Time 1 Recommending the university, and Time 1 Active Alumni Intent with Time 2 Social Connectedness, Time 2 Self-Esteem, Time 2 Recommending the university and Time 2 Active Alumni Intent

\begin{tabular}{|c|c|c|c|c|c|c|c|c|c|c|c|}
\hline Variable & M & SD & 1 & 2 & 3 & 4 & 5 & 6 & 7 & 8 & 9 \\
\hline 1. Time 1 Wait Time ${ }^{\mathrm{a}}$ & 14.07 & 7.64 & (NA) & & & & & & & & \\
\hline $\begin{array}{l}\text { 2. Time } 1 \text { Social } \\
\text { Connectedness }^{\mathrm{b}}\end{array}$ & 4.26 & 1.57 & -.20 & $(.90)$ & & & & & & & \\
\hline 3. Time 1 Self-Esteem ${ }^{c}$ & 4.43 & 1.67 & -.16 & $.41^{* *}$ & $(.94)$ & & & & & & \\
\hline $\begin{array}{l}\text { 4. Time } 1 \text { Recommending } \\
\text { the university }^{\mathrm{d}}\end{array}$ & 5.72 & 1.30 & $-.28 *$ & $.52 * *$ & .06 & $(.96)$ & & & & & \\
\hline $\begin{array}{l}\text { 5. Time } 1 \text { Active Alumnus } \\
\text { Intent }^{\mathrm{e}}\end{array}$ & 4.69 & 1.35 & -.17 & $.31 *$ & $.28^{*}$ & $.51^{* *}$ & $(.85)$ & & & & \\
\hline $\begin{array}{l}\text { 6. Time } 2 \text { Social } \\
\text { Connectedness }^{\mathrm{b}}\end{array}$ & 4.66 & 1.41 & -.04 & $.77 * *$ & $.42 * *$ & $.40^{* *}$ & $.29^{*}$ & $(.92)$ & & & \\
\hline 7. Time 2 Self-Esteem ${ }^{c}$ & 4.78 & 1.74 & -.21 & $.34 * *$ & $.85 * *$ & .11 & $.28^{*}$ & $.45 * *$ & $(.96)$ & & \\
\hline $\begin{array}{l}\text { 8. Time } 2 \text { Recommending } \\
\text { the university }\end{array}$ & 5.90 & 1.09 & -.10 & $.38^{* *}$ & .10 & $.79 * *$ & $.49^{* *}$ & $.41^{* *}$ & .19 & $(.93)$ & \\
\hline $\begin{array}{l}\text { 9. Time } 2 \text { Active Alumnus } \\
\text { Intent }^{\mathrm{e}}\end{array}$ & 4.89 & 1.37 & -.19 & .19 & $.32 *$ & $.47^{* *}$ & $.80^{* *}$ & $.26^{*}$ & $.41^{* *}$ & $.49^{* *}$ & $(.89)$ \\
\hline
\end{tabular}

Note. $\mathrm{N}=60 .{ }^{*} \mathrm{p}<.05 ; * * \mathrm{p}<.01$ (two-tailed). Listwise deletion of data. Effect Size (Cohen, 1988), $d=\mathrm{M}($ Time 1) - M(Time $2) / \sqrt{ }$ pooled $\mathrm{SD} ; \underline{\mathrm{r}}>.38$ (large); $\underline{\mathrm{r}}>.24$ (medium); $\underline{\mathrm{r}}>.10$ (small). Cronbach's alpha reported in parentheses, NA $=$ not applicable.

${ }^{a}$ Time 1 Wait Time measured in days; All other variables measured on 7-point response scale, $1=$ strongly disagree to $7=$ strongly agree.

${ }^{\mathrm{b}}$ Paired-Samples t-test, Social Connectedness T1 - T2, $\mathrm{t}(59)=-2.98, \mathrm{p}=.002$ (one-tailed), $d=.32$.

${ }^{\mathrm{c}}$ Paired-Samples t-test, Self-Esteem T1 - T2, $\mathrm{t}(59)=-2.95, \mathrm{p}=.002$ (one-tailed), $d=.27$.

${ }^{\mathrm{d}}$ Paired-Samples t-test, Recommending the university T1 - T2, $\mathrm{t}(59)=-1.74, \mathrm{p}=.044$ (one-tailed), $d=.17$.

${ }^{\mathrm{e}}$ Paired-Samples t-test, Active Alumnus Intent T1 - T2, t $(59)=-1.79, \mathrm{p}=.040$ (one-tailed), $d=.17$.

\subsection{Testing the Hypotheses}

Hypothesis 1 (H1) was tested using paired sample t-tests for change from Time 1 to Time 2. The t-test results in Table 2 showed significant mean increases ( $p<.05$, one-tailed) from Time 1 to Time 2 for social connectedness, $\mathrm{t}(59)=-2.98$; self-esteem, $\mathrm{t}(59)=-2.95$; recommending the university, $\mathrm{t}(59)=-1.74$ and active alumnus intent, $\mathrm{t}(59)$ $=-1.79$. However, after applying the Bonferroni correction of .05 significance $/ 3$ hypotheses, $p=.0167$, only the mean increases for social connectedness and self-esteem adjustment remained significant. In addition, the effect sizes (Cohen, 1988) of recommending the university and active alumnus intent were weak $(d<.20)$, while social connectedness and self-esteem were medium $(d<.50)$. Overall, there was partial support for H1, i.e., brief counseling will increase social connectedness, self-esteem, recommending the university and active alumnus intent.

Hypothesis 2 (H2) was tested using within-time period and across time period correlation analyses. As shown in Table 2, for within time or cross-sectional correlations for Time 1 and Time 2, social connectedness had significant positive relationships to recommending the university (Time $1, r=.52$ and Time $2, r=.38$ ) and active alumni intent (Time 1, $r=.31$ ) but not at Time 2, $r=.19$ ). Self-esteem had a positive correlation to active alumni intent at Time $1(r=.28)$ and Time $2(r=.32)$, but not to recommending the university (Time $1, r=.06$ and Time $2, r=.10)$. Testing across time correlations, Time 1 social connectedness had a positive relationship to Time 2 recommending the university $(r=.38)$, but not to Time 2 active alumnus intent $(r=.19)$. Time 1 self-esteem had a positive 
relationship to Time 2 active alumnus intent $(r=.32)$ but not to Time 2 recommending the university $(r=.10)$. The effect sizes for these two significant across time correlations were medium (Cohen, 1988). Overall, there was partial support for $\mathrm{H} 2$, i.e., social connectedness had a stronger positive relationship to recommending the university, while self-esteem had a stronger positive relationship to active alumnus intent.

The hierarchical regression model results for testing $\mathrm{H} 3$ are shown in Table 3. Time 1 independent variables were used to test for the impact on Time 2 dependent variables. Looking at recommending the university first, for Model $1,15 \%$ of the variance in recommending the university was accounted for collectively by all three background variables (gender, ethnic background and wait time). Within this background variable set, ethnic background was significant ( $b=.82$, white higher). For model 2, when the client perception variables of social connectedness and self-esteem were added, an additional $7 \%$ of the variance in recommending the university was accounted for. Within this model, ethnic background continued to be significant ( $b=.64$, white higher) and social connectedness was also significant $(b=.20)$. Overall, $22 \%$ of the variance was accounted for in recommending the university.

Looking at active alumnus intent in Model 1, 6\% of the variance in active alumnus intent was accounted for collectively by all three background variables (gender, ethnic background and wait time). Within this background variable set, no individual variables were significant. For Model 2, when the client perception variables of social connectedness and self-esteem were added, an additional $9 \%$ of the variance in active alumnus intent was accounted for. Within this step, only self-esteem was significant $(b=.23)$. Overall, $14 \%$ of the variance was accounted for in active alumnus intent. There was partial support for H3, i.e., beyond controlled-for background variables, social connectedness accounted for significant variance in recommending the university, while self-esteem accounted for significant variance in active alumnus intent.

Table 3. Hierarchical Regression Analyses of Time 1 Variables on Time 2 Recommending the university and Active Alumnus Intent

\begin{tabular}{|c|c|c|c|c|}
\hline \multirow{2}{*}{$\begin{array}{l}\text { Time } 2 \text { Dependent Variable } \\
\text { Independent Variable }\end{array}$} & \multicolumn{2}{|c|}{ Recommending the university } & \multicolumn{2}{|c|}{ Active Alumnus Intent } \\
\hline & Model 1 & Model 2 & Model 1 & Model 2 \\
\hline \multicolumn{5}{|c|}{ Step 1 - Time 1 Background Variables } \\
\hline Gendera & $.37(.38)$ & $.23(.38)$ & $.50(.50)$ & $.52(.50)$ \\
\hline Ethnic Backgroundb & $.82 * *(.30)$ & $.64 *(.31)$ & $-.17(.40)$ & $-.23(.40)$ \\
\hline Wait Time & $-.01(.02)$ & $.01(.02)$ & $-.03(.02)$ & $-.02(.02)$ \\
\hline \multicolumn{5}{|c|}{ Step 2 - Time 1 Client Perceptions } \\
\hline Social Connectedness & & $.20 *(.10)$ & & $.04(.13)$ \\
\hline Self-Esteem & & $-.02(.09)$ & & $.23 *(.11)$ \\
\hline $\mathrm{F}$ & $3.23 *$ & $2.97 *$ & 1.09 & 1.79 \\
\hline Degrees of freedom & 3,56 & 5,54 & 3,56 & 5,54 \\
\hline $\mathrm{R} 2$ & .148 & .216 & .055 & .142 \\
\hline Change in $\mathrm{R} 2$ & & .068 & $.087+$ & \\
\hline
\end{tabular}

Note. Unstandardized regression coefficients reported (standard error), rounded to hundredths. $\mathrm{N}=60$;

$+\mathrm{p}<.10 ; * \mathrm{p}<.05 ; * * \mathrm{p}<.01 ;$

agender $(1=$ male, 2 = female $)$; ${ }^{\mathrm{a}}$ ethnic background $(1=$ non-white, 2 = white $)$.

\subsection{Descriptive Data Results - Control Sample}

Table 4 shows the means, standard deviations, scale reliabilities and correlations for the four scales: social connectedness, self-esteem, recommending the university, and active alumni intent. All scales had good reliabilities, and given the large sample size, significant positive correlations. More interesting is comparing the scale means to the Time 2 counseled sample means. The social connectedness mean of the Control group $(M=5.06)$ was higher than the Time 2 social connectedness mean $(M=4.66)$. The self-esteem mean of the Control group ( $M$ $=5.88)$ was much higher than the Time 2 self-esteem mean $(M=4.78)$. The recommending the university mean of the Control group $(M=5.71)$ was lower than the Time 2 recommending the university mean $(M=5.90)$. Finally, 
the active alumni intent mean of the Control group $(M=4.91)$ was essentially the same as the Time 2 active alumni intent mean (4.89).

Table 4. Means, Standard Deviations, Scale Reliabilities and Correlations for the Control Sample

\begin{tabular}{lllllll}
\hline Variable & M & SD & $\mathbf{1}$ & $\mathbf{2}$ & $\mathbf{3}$ & $\mathbf{4}$ \\
\hline 1. Social Connectedness & 5.06 & 1.33 & $(.91)$ & & & \\
2. Self-esteem & 5.88 & .98 & $.38^{* *}$ & $(.90)$ & & \\
3. Recommending the university & 5.71 & 1.22 & $.52^{* *}$ & $.33^{* *}$ & $(.95)$ & \\
4. Active Alumni Intent & 4.91 & 1.40 & $.51^{* *}$ & $.28^{* *}$ & $.60^{*}$ & $(.89)$ \\
\hline
\end{tabular}

Note. $\mathrm{N}=857 . * * \mathrm{p}<.01$ (two-tailed). Listwise deletion of data.

\section{Discussion}

Finding that brief counseling had a positive impact on non-urgent client social connectedness and self-esteem was consistent with prior research (CCMH, 2016; Mahon et al., 2015). These findings reinforce the importance of the therapeutic alliance (Pinkerton et al., 2009). The research design used was unique in finding that brief counseling had a positive impact on recommending the university and active alumnus intent. In addition, over time, social connectedness had a significant positive relationship to recommending the university, while self-esteem had a significant positive relationship to active alumnus intent. These findings reinforce Bishop's (2010) observation that a UCC is typically an "undervalued resource in recruitment, retention and risk management" (p.248). Twenty years ago, researchers (Archer \& Cooper, 1998; Corazzini, 1997) argued that if UCCs can provide counseling services that directly help a university or college to meet its academic mission or goals, the value of counseling would be salient to not just students-served and counseling staff but to broader groups of stakeholders, including administrators and faculty.

In this study, counseled students who felt more socially connected, were more likely to recommend their university to friends and family. General research with college students has suggested that social inclusion can be a factor in recommending their university (Douglas, Douglas, McClelland \& Davies, 2015). With college students having increased access to friends and family via social media, such recommendations can help a university to meet its general academic mission/goal of at least stability, if not growth, in enrollment (Hamadeh \& Khoueiri, 2010). An unexpected robust finding across both regression models was that white counseled students were more likely to recommending the university than non-white counseled students. Additional study for this finding is needed. For example, how might the counseling experience at the UCC be different for white versus non-white clients? However, this finding must be tempered by noting the smaller sample sizes, especially for the non-white counseled subgroup which was composed of ethnicities that were aggregated (i.e., African American, Asian, Hispanic or Latino, and multi-racial).

Counseled students, who felt better about themselves through increased self-esteem, had a stronger intent to become active alumni in the future. As suggested earlier, the UCC therapist can represent the institution when a student feels vulnerable and in need of help. The therapeutic alliance can help a client's personal and social growth (Pinkerton et al., 2009). General research has found that how students perceived their college's contribution to their personal and social growth increased the likelihood of becoming an alumnus donor (Thomas \& Smart, 2005). Alumni monetary contributions are one source of revenue for many universities and colleges (Worth, 2002). However, an active alumnus can also donate time, e.g., by mentoring a current student or interviewing a potential one (Torres Bernal \& Mille, 2014).

Despite the loss in client sample size over time, the Time 1 and Time 2 samples exhibited the same general background variable composition. The two outcome scales, recommending the university and active alumnus intent, exhibited strong internal consistencies and test-retest reliabilities. In addition, social connectedness and self-esteem were valid, shortened versions of longer scales. They also showed strong internal consistencies and test-retest reliabilities

Despite demographic differences on gender and ethnicity, the control or non-counseled sample provides additional perspective on the counseled sample results. Prior research has shown that non-counseled students will have higher means on well-being and social adjustment variables (Green et al., 2003). However, no research has compared the variable means of counseled versus non-counseled students on recommending university or active 
alumni intent. The counseled sample at Time 2 compared favorably to the non-counseled sample on both of these variables.

\subsection{Study Limitations and Future Research}

Given the nature of this study, i.e., using a non-urgent sample of briefly counseled clients to test the relationships of social connectedness and self-esteem to two non-typical outcomes, recommending the university and active alumnus intent, the results found should be viewed as promising. One study limitation was that only brief counseling was tested and there were no standardized procedures to assess the therapeutic methods employed during the brief counseling. There were no also controls for assessing the number of therapists or the same therapist counseling different respondents over the course of the study. Surrette and Shier's (2017) sample consisted of four counselors across 102 clients who participated in at least three counseling sessions. They found that different therapeutic interventions had a limited impact on improving somatization, depression and anxiety symptoms. The brief counseling sample here reported a median of three counseling sessions after intake (range 1 to 8) over a median period of six weeks (range 4 to 10 weeks). The study did not collect demographic information about the counselors. A lack of demographic consistency between the clients and counselors could impact the non-white student perceptions of their counseling experiences. Previous research has found that racial match in counseling correlates with client satisfaction and perceptions of the quality of care (Meyer \& Zane, 2013). In addition, only non-urgent clients were sampled.

The loss in client sample size over time was another limitation. This client loss was consistent with prior research (e.g., Draper et al., 2002; Ghetie, 2007; Lucas, 2012; Mahon et al., 2015). Archival data from the UCC study site showed that, one is the most frequent number of sessions for a non-urgent client (consistent with the CCMH, 2017), and that by four sessions (triage plus three sessions after), counseling had terminated for most non-urgent clients. By becoming part of a larger UCC site network so that common data collection can be aggregated (Kopta et al., 2014), a UCC can overcome the problem of insufficient data from only one site.

All data was self-reported and no record-based measures were used. In addition, since clients were still students and had not graduated, only intent to become an active alumnus was measured. It would be ideal to track, where possible, if a current or past counseling client's recommendation to attend had an impact on a prospective student applicant's application or his/her matriculation decision. It would also be ideal to track if positive experiences at the university, including counseling, had an impact on graduated students becoming active alumni (Torres Bernal \& Mille, 2014). Only limited amounts of variance were accounted for in recommending the university and active alumnus intent. These findings are representative of an exploratory study. The results were found with a limited sample of briefly counseled non-urgent undergraduates at the UCC of a large state-supported mid-Atlantic urban university. Other counseling samples from other types of UCCs (e.g., private, non-urban) are needed to test the generalizability of these initial findings. For instance, the Control group was comprised of only business undergraduates. In addition, it is important to acknowledge that the much larger size of this control group, compared to the counseled sample over time, made direct statistical comparisons between variable means unfair (Cooper \& Richardson, 1986).

\section{Implications for Resourcing UCCs}

UCCs compete with other university stakeholders for limited resources. Very broadly, such stakeholders can range from athletic departments and new/renovation building funding, to academic research center initiatives. Within the student affairs division (where a UCC is typically found), competitive stakeholders can include student housing, disability resources and services, and student health services. By showing its university administration that the UCC is helping distressed students, this should ideally allow the UCC to increase its resource allocation to match demand (Bishop, 2010; Kitzrow, 2009). However, beyond more traditional measures such as the BMH (Kopta et al., 2014), or CCAPS (Brunner et al., 2014), UCC-site research efforts which also incorporate variables more directly linked to the academic mission of a university or college, should be considered where-ever possible.

Showing that counseling helps with student retention (Lee et al., 2009) or student academic performance (AUCCCD, 2016) fits within the academic mission. The results of this exploratory study suggest that extending this network of academic mission variables to recommending university and active alumnus intent may be useful. These can become additional variables to consider as a UCC undertakes its own research or works with a consortium of UCCs (Kopta et al., 2014). Such an extension may be especially important for UCCs facing a flat budget model, where greater rapid access services are increasingly provided but routine treatment of non-urgent clients may suffer (CCMH, 2017). Showing how a UCC improves the mental health of its students, as well as helping the university to meet its broader academic goals, should increase the likelihood of the UCC getting needed resources. This would allow UCCs to keep pace with increasing student mental health demands. To better 
prepare for the future success of its student populations and university enrollments, UCCs need to consider new avenues to promote their advocacy by gathering data more directly connected to a university's mission.

\section{References}

Archer, J. A., Jr., \& Cooper, S. E. (1998). Counseling and mental health services on campus. San Francisco: Jossey-Bass.

AUCCCD. (2016). The association for university and college counseling center directors annual Survey. Reetz, D. R., Bershad, C. \& LeVines, P.

Bishop, J. B. (2010). The counseling center: An undervalued resource in recruitment, retention and risk

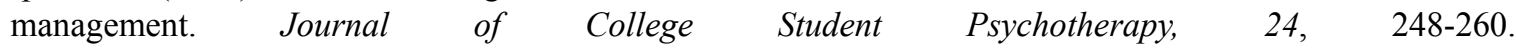
https://doi.org/10.1080/87568225.2010.509219

Blau, G., DeMaria, P. A., Jr., \& DiMino, J. (2017). Correlates of a university counseling center's perceived service promptness. Journal of Educational and Developmental Psychology, 7(2), 24-32. https://doi.org/10.5539/jedp.v7n2p24

Blau, G., DiMino, J., Sheridan, N., Stein, A., Casper, S., Chessler, M., \& Beverly, C. (2015). Wait time for counseling affecting perceived stigma and attitude toward the University. College Student Journal, 49(2), 280-290.

Blau, G., DiMino, J., DeMaria Jr., P. A., Beverly, C., \& Chessler, M. (2016). Mental health concerns' impact on graduation intent and improvement for brief counseling. Journal of Assessment and Institutional Effectiveness, 6(2), 142-164. https://doi.org/10.5325/jasseinsteffe.6.2.0142

Browne, B. A., Kaldernberg, D. O., Browne, W. G., \& Brown, D. J. (1998). Student as customer: Factors affecting satisfaction and assessments of institutional quality. Journal of Marketing for Higher Education, 8(3), 1-14. https://doi.org/10.1300/J050v08n03_01

Brunner, J. L., Wallace, D. L., Reymann, L. S., Sellers, J-J., \& McCabe, A.G. (2014). College counseling today: Contemporary students and how counseling centers meet their needs. Journal of College Student Psychotherapy, 28, 257-324. https://doi.org/10.1080/87568225.2014.948770

Cohen, J. (1988). Statistical power analysis for the behavioral sciences (2nd Ed.). Hillsdale, NJ: Lawrence Earlbaum Associates.

Cooper W. H., \& Richardson, A. J. (1986). Unfair comparisons. Journal of Applied Psychology, 71(2), 179-184. https://doi.org/10.1037/0021-9010.71.2.179

Corazzini, J. G. (1997). Using research to determine the efficacy and modes of treatment in University Counseling Centers: Comment on the Jobes, Jacoby, Cimbolic, and Hustead (1997) and Hayes (1997). Journal of Counseling Psychology, 44(4), 378-380. https://doi.org/10.1037/0022-0167.44.4.378

Davidson, W. B., Beck, H. P., \& Milligan. M. (2009). The College Persistence Questionnaire: development and validation of an instrument that predicts student attrition. Journal of College Student Development, 50(4), 373-390. https://doi.org/10.1353/csd.0.0079

DeStefano, T. J., Mellott, R. N., \& Petersen. J. D. (2001). A preliminary assessment of the impact of counseling on student adjustment to college. Journal of College Counseling, 4(2), 113-121. https://doi.org/10.1002/j.2161-1882.2001.tb00191.x

Douglas, J. A., Douglas, A., McClelland, R. J., \& Davies, J. (2015). Understanding student satisfaction and dissatisfaction: An interpretive study in the UK higher education context. Studies in Higher Education, 40(2), 329-349. https://doi.org/10.1080/03075079.2013.842217

Draper, M. R., Jennings, J., Baron, A., Erdur, O., \& Shankar, L. 2002. Time-limited counseling outcome in a nationwide college counseling center sample. Journal of College Counseling, 5(1), 26-38. https://doi.org/10.1002/j.2161-1882.2002.tb00204.x

Ellison, N. B., Steinfield, C., \& Lampe, C. (2007). The benefits of Facebook "friends:" Social capital and college students' use of online social network sites. Journal of Computer-Mediated Communication, 12, 1143-1168. https://doi.org/10.1111/j.1083-6161.2007.00367.x

Ghetie, D. (2007). The debate over time-limited treatment in college counseling centers. Journal of College Student Psychotherapy, 22(1), 41-61. https://doi.org/10.1300/J035v22n01_04

Green, J. L., Lowry, J. L., \& Kopta, M. (2003). College students versus college counseling center clients. Journal 
of College Student Psychotherapy, 17(4), 25-37. https://doi.org/10.1300/J035v17n04_05

Greenberger, E., Chen, C., Dmitrieva, J., \& Farruggia, S. P. (2003). Item-wording and the dimensionality of the Rosenberg Self-Esteem scale: Do they matter? Personality and Individual Differences, 35, 1241-1254. https://doi.org/10.1016/S0191-8869(02)00331-8

Hamadeh, M., \& Khoueiri, R. (2010). Demand elasticities for higher education in the United States. International Journal of Business and Economics Perspectives, 5(2), 60-67.

IACS. (2010). Accreditation for the university and college counseling services. Alexandria, VA: International Association of Counseling Services, Inc.

Joslyn, H. (2018, February 6). Giving to colleges up 6\% in 2017. The Chronicle of Philanthropy. accessed $5 / 11 / 2018$.

Kitzrow, M. A. (2009). The mental health needs of today's college students: Challenges and recommendations. NASPA Journal, 46(4), 646-660. https://doi.org/10.2202/1949-6605.5037

Kopta, S. M., Petrik, M. L., Saunders, S. M., Mond, M., Hirsch, G., Kadison, R., \& Raymond, D. (2014). The utility of an efficient outcomes assessment system at university counseling centers. Journal of College Student Psychotherapy, 28, 97-116. https://doi.org/10.1080/87568225.2014.883876

Lee, D., Olson, E. A., Locke, B. Testa Michelson, S., \& Odes, E. (2009). The effects of college counseling services on academic performance and retention. Journal of College Student Development, 50(3), 305-319. https://doi.org/10.1353/csd.0.0071

Lucas, M. S. (2012). Counseling on campus: Client persistence and progress. Journal of College Student Psychotherapy, 26, 227-240. https://doi.org/10.1080/87568225.2012.685856

Mahon, M., Laux, J. M., McGuire Wise, S., Ritchie, M. H., Piazza, N. J., \& Tiamiyu, M. (2015). Brief therapy at a university counseling center: working alliance, readiness to change, and symptom severity. Journal of College Counseling, 18, 223-243. https://doi.org/10.1002/jocc.12017

Meyer, O. L., \& Zane, N. (2013). The influence of race and ethnicity in clients' experiences of mental health treatment. Journal of Community Psychology, 41(7), 884-901. https://doi.org/10.1002/jcop.21580

Mowbray, C. T., Megivern, D., Mandiberg, J. M., Strauss, S., Stein, C. H., Collins, K....Lett, R. (2006). Campus mental health services: Recommendations for change. American Journal of Orthopsychiatry, 76(2), 226-237. https://doi.org/10.1037/0002-9432.76.2.226

Nunnally, J. C. (1978). Psychometric theory (2nd ed.). New York, NY: McGraw-Hill.

Pinkerton, R., Talley, J. E., \& Cooper, S. L. (2009). Reflections on individual psychotherapy with university students: What seems to work. Journal of College Student Psychotherapy, 23, 153-171. https://doi.org/10.1080/87568220902793830

Raju, D., \& Schumacker. R. (2015). Exploring student characteristics of retention that lead to graduation in higher education using data mining models. Journal of College Student Retention, 16(4), 563-591.

Rosenberg, M. (1965). Society and the adolescent self-image. Princeton, NJ: Princeton University Press. https://doi.org/10.1515/9781400876136

Roth, P. L. (1994). Missing data: A conceptual review for applied psychologists. Personnel Psychology, 47(3), 537-560. https://doi.org/10.1111/j.1744-6570.1994.tb01736.x

SPSS. (2013). Statistical package for the social sciences (Version 22). Armonk, NY: IBM.

Stevens, J. P. (1996). Applied multivariate statistics for the social sciences (3rd ed.). Mahwah, NJ: Erlbaum.

Surette, T. E., \& Shier, M. L. (2017). A common factors approach to supporting university students experiencing psychological distress. Journal of College Student Psychotherapy, 31(2), 112-131. https://doi.org/10.1080/87568225.2016.1248233

Thomas, J. A., \& Smart, J.C. (2005, May). The relationship between personal and social growth, involvement in college and subsequent alumnus giving. Paper presented at the meeting of the Association for Institutional Research. San Diego, CA. Retrieved from https://eric.ed.gov/?id=ED491032

Torres Bernal, A., \& Mille, D. (2014). Initiating alumnus engagement initiatives: Recommendations from MFT alumnus focus groups. Contemporary Family Therapy, 36, 300-309. https://doi.org/10.1007/s10591-013-9274-2 
Vianden, J. (2015). What matters in college to students: Critical incidents in the undergraduate experience. Journal of Student Affairs Research and Practice, 52(3), 287-299. https://doi.org/10.1080/19496591.2015.1067226

Weerts, D. J., \& Ronca, J. M. (2007). Profiles of supportive alumnus: Donors, volunteers, and those who "do it all." $\begin{array}{llll}\text { International Journal of Educational Advancement, } & 7(1), & \text { 20-34. }\end{array}$ https://doi.org/10.1057/palgrave.ijea.2150044

Williams, M. G., \& Kritsonis, W. A. (2006). Raising money at the nation's historically black colleges and universities. National Journal for Publishing and Mentoring Doctoral Research, 3, 1-5.

Worth, M. J. (Ed.). (2002). New strategies for educational fundraising. Westport: Praeger.

\section{Copyrights}

Copyright for this article is retained by the author(s), with first publication rights granted to the journal.

This is an open-access article distributed under the terms and conditions of the Creative Commons Attribution license (http://creativecommons.org/licenses/by/4.0/). 